\title{
PENGUKURAN KINERJA EFEKTIF \\ DEPARTEMEN PENGEMBANGAN SISTEM INFORMASI DENGAN METODE BALANCED SCORECARD PADA PT XYZ
}

\author{
Eli Suryani; Muhammad Fadli \\ Information Systems Department, School of Information Systems, Binus University \\ Jl. K.H. Syahdan No. 9, Palmerah, Jakarta Barat 11480 \\ esuryani@gmail.com
}

\begin{abstract}
Department of Information System Development at PT XYZ becomes a trigger in the movement of the Information Technology Development of the company. However it is not merely the fastest, the biggest or the most completed project that determine the success, but the most important is to align with the business strategy due to achieve the company's goal and objective. Recognizing the performance does not only need a measurement system but also right measurements. The purpose of the study is to design an effective Key Performance Indicator in Departement of Information System Development that is aligned with current indicators to measure the success of company's strategy execution. The choosen indicators are cascaded from company's strategy map and information technology strategy map. The design uses balanced scorecard method according to data and information collected from executive interview, focus group discussion and workshop with the key persons in IT organization. Balanced scorecard method provides the integration of financial and nonfianncial factor for measurements. It allows different level formulation with same performance indicator flexibly. Recently, Department of Information System Development can monitor and develop its performance directionally.
\end{abstract}

Keywords: information technology, strategy map, balanced scorecard, key performance indicator

\begin{abstract}
ABSTRAK
Departemen Pengembangan Sistem Informasi PT XYZ menjadi departemen pemicu terhadap kemajuan perkembangan Teknologi Informasi perusahaan. Pengembangan yang berhasil bukanlah yang tercepat, terbesar ataupun penyelesaian terbanyak, tapi yang yang searah dengan strategi bisnis dan mancapai target perusahaan. Untuk mengetahui keberhasilannya tidak hanya diperlukan sistem pengukuran tapi juga cara mengukur yang tepat. Tujuan penelitian ini adalah merancang Key Performance Indicator yang efektif dan selaras dengan indikator keberhasilan pencapaian strategi perusahaan pada Departemen Pengembangan Sistem Informasi. Pengukuran kinerja akan diturunkan dari peta strategi perusahaan dan peta strategi teknologi informasi perusahaan. Metode yang digunakan adalah Balanced Scorecard yang dirancang berdasarkan hasil analisis data dan informasi yang dikumpulkan dari executive interview, focus group discussion dan workshop bersama dengan orang kunci organisasi Teknologi Informasi. Metode balanced scorecard telah menyediakan pengukuran kinerja yang terintegrasi antara faktor finansial dan non-financial, dan fleksibel dalam memformulasi pengukuran yang berbeda tingkatan pada indikator performa yang sama. Kini, Departemen Pengembangan Sistem Informasi dapat melakukan pengawasan dan pengembangan kinerjanya secara secara lebih terarah.
\end{abstract}

Kata kunci: teknologi informasi, peta strategi, balanced scorecard, key performance indicator 


\section{PENDAHULUAN}

PT XYZ adalah salah satu perusahaan pembiayaan terbesar saat ini untuk barang kendaraan bermotor dan peralatan berat, baik skala retail ataupun korporasi (fleet). Pada Mei 2010, Industri ini semakin lama semakin meningkat dari satu dekade ke dekade berikutnya. Potensi pertumbuhan yang menjanjikan inilah yang membuat kompetisi semakin marak dengan masuknya pesaing-pesaing baru yang jumlahnya semakin meningkat dari waktu ke waktu.

TI telah menjadi salah satu komponen business enabler bagi PT XYZ dan menempati posisi yang strategis bagi perusahaan dalam berkompetisi dan mencapai tujuan perusahaan. Oleh sebab itu, penting bagi TI untuk secara terus menerus menjadi partner strategis dengan bisnis dan sejalan dengan tujuan perusahaan (Suryani \& Fadli, 2011). Meskipun pimpinan perusahaan berkomitmen untuk mensinergikan strategi bisnis dan teknologi informasi, mereka ingin memastikan terjadinya kontrol yang efektif terhadap organisasi teknologi informasi. Langkah strategi TI yang diambil perlu memastikan fokus yang tepat sasaran dan sejalan dengan strategi dan prioritas perusahaan, agar mendapatkan hasil yang senilai dengan nilai investasi dan pengalokasian keuangan yang seimbang. Untuk itu perlu dibangun sistem pengukuran untuk mengevaluasi kinerja organisasi pada masingmasing stuktur bagian yang ada dibawah divisi teknologi informasi.

Kinerja menurut Mulyadi (2001) adalah istilah umum yang digunakan untuk menunjukkan sebagian atau seluruh tindakan atau aktivitas dari suatu organisasi pada suatu periode. Kinerja adalah suatu tampilan keadaan secara utuh atas perusahaan selama periode waktu tertentu, merupakan hasil atau prestasi yang dipengaruhi oleh kegiatan operasional perusahaan dalam memanfaatkan sumbersumber daya yang dimiliki.

Untuk mengetahui keberhasilan sebuah perusahaan dalam menjalankan bisnisnya perlu dilakukan pengukuran kinerja. Balanced Scorecard adalah teknik yang dibangun pertamakali oleh Kaplan dan Norton (1992) yang membantu para pembuat keputusan dalam organisasi untuk mengarahkan organisasi kepada keberhasilan. Teknik ini memampukan organisasi untuk menterjemahkan misi dan strategi kedalam sebuah paket pengukuran kinerja yang komprehensif yang menyediakan kerangka kerja untuk sebuah pengukuran yang strategis. Balanced Scorecard merupakan strategi pengukuran kinerja organisasi dengan menentukan target dan ukuran tertentu, yang mengaitkan strategi dan pengukuran kepada strategi dan pengukuran penting yang diimplementasikan dalam bisnis (Kaplan dan Northon, 2001), diturunkan pada organisasi mulai dari bisnis unit sampai dengan level karyawan (Niven, 2002).

Pengajuan pengukuran kinerja Divisi TI yang telah diajukan sebelumnya kepada Chief Information Officer (CIO) PT XYZ belum dianggap relevan terhadap bahasa dan ukuran keberhasilan yang diukur oleh bisnis. Strategi IT dinilai belum optimal bagi manajemen puncak pada saat itu. Sehingga pada tahun 2011 dilakukan pengembangan ulang sistem pengukuran kinerja dengan metode balanced scorecard pada Divisi TI yang menurunkan beberapa key performance indicator (KPI) penting dari strategi bisnis perusahaan yang dapat didukung penuh secara langsung oleh teknologi informasi.

Menurut survey yang dilakukan Kaplan and Norton (2004), seringkali suatu strategi menjadi sulit untuk diimplementasikan bahkan di organisasi yang telah dianggap matang. Salah satu penyebab terbesarnya adalah dikarenakan sedikit dari karyawan yang mengerti strategi perusahaan, sehingga pelaksanaan strategi kerja setiap individu tidak searah dengan strategi organisasi. Dan Niven (2002) menyatakan ada dua masalah yang berkembang dalam sebuah bisnis, yaitu bagaimana mengukur kinerja organisasi secara efektif dan keberhasilan dalam pencapaian strategi, di mana perusahaan gagal 
untuk menyediakan informasi dalam bentuk yang dibutuhkan, dimengerti dan unik untuk setiap karyawan relevan dengan tugas mereka.

Dengan mempertimbangkan hal itu, tidak cukup sistem pengukuran performa hanya diturunkan sampai dengan level divisi saja, di mana perusahaan berharap setiap individu dapat memacu performanya bergerak untuk mencapai puncak performa Divisi TI secara menyeluruh. Oleh karena penurunan Key Performance Indicator perlu dilanjutkan ke bagian Departemen- departemen pendukungnya. Penelitian ini membahas pembangunan pengukuran performa departemen yang diturunkan dari performa divisi, yang diprioritaskan pada departemen terbesar di Divisi TI, yakni Department of Information System Development atau departemen pengembangan sistem informasi.

\section{METODE}

Tahapan dalam melakukan analisis dan pembangunan Balanced Scorecard sebagai hasil tujuan penelitian digambarkan sebagai berikut (Gambar 1):

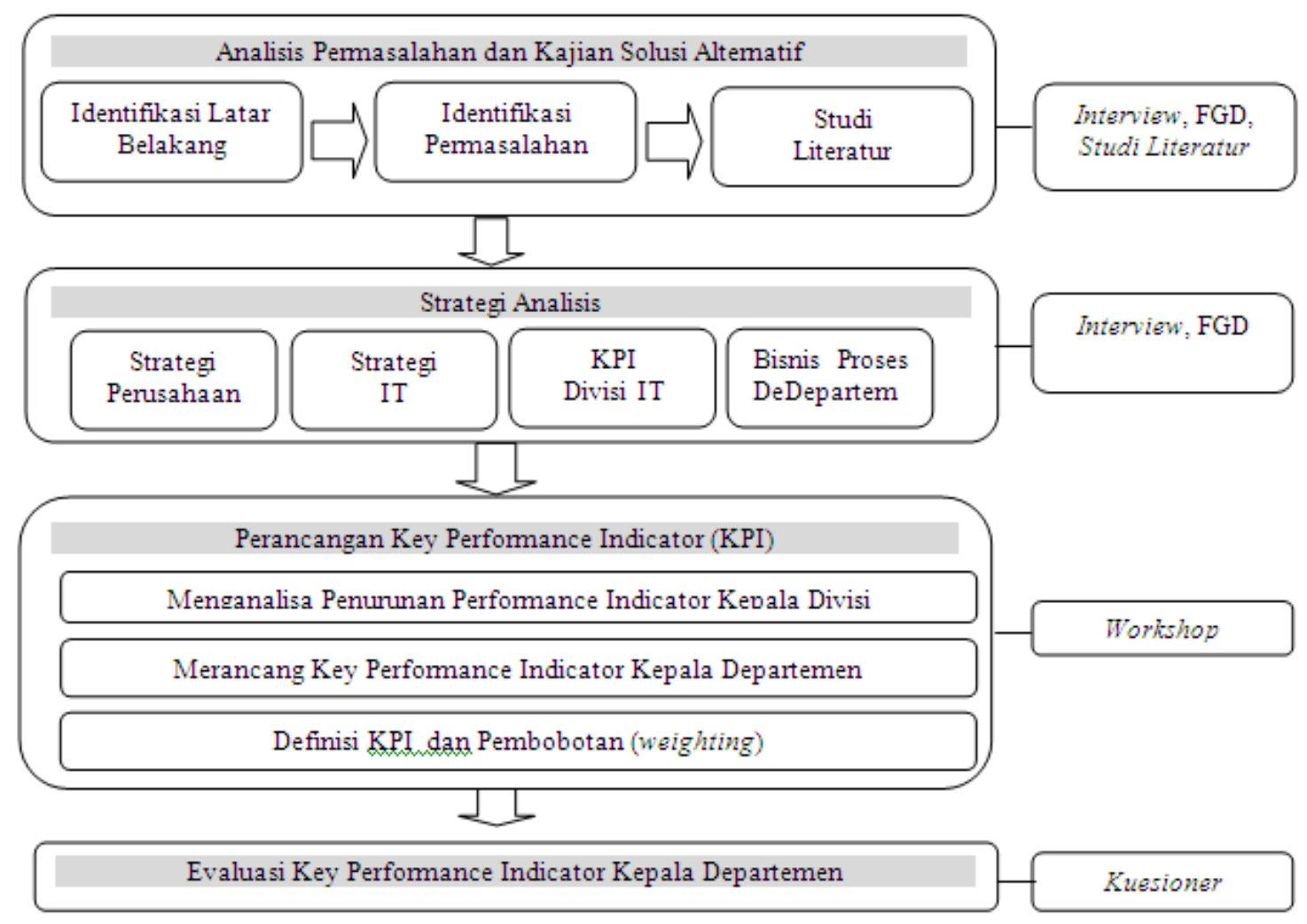

Gambar 1 Kerangka pikir penelitian

\section{Tahap Analisis}

\section{Analisis Permasalahan dan Mengkaji Solusi Alternatif}

Pada tahapan ini dilakukan executive interview bersama dengan Kepala Divisi IT dan Kepala Departemen pengembangan sistem informasi perusahaan, untuk memahami kondisi secara umum baik secara internal dan eksternal, memahami struktur, bisnis proses, mengkaji kinerja dan permasalahan 
dihadapi yang memiliki prioritas penting untuk diatasi. Dilakukan kajian literatur dari berbagai sumber jurnal dan artikel online dan studi pustaka, untuk mengatasi permasalahan yang dihadapi perusahaan.

\section{Strategi Analisis}

Pada tahapan ini, dilakukan exekutif interview bersama Kepala Divisi Kepala Departemen pengembangan sistem untuk mengkoleksi beberapa informasi penting terkait strategi TI yang diturunkan dari strategi perusahaan, KPI Divisi TI, mengkaji bisnis proses dan proses-proses utama yang dilakukan, kebijakan-kebijakan khusus yang diberlakukan, pada tahapan ini juga dilakukan Focus Group Discussion dengan Department Head, Section Head dan Business System Analyst dari departemen pengembangan sistem informasi untuk mendapatkan pemahaman mengenai keungulan, kelemahan, peluang dan tantangan yang sedang dihadapi. Kemudian kami menganalisis tingkat kepuasan pelanggan internal, kesesuaian dengan fokus strategi pada periode berjalan.

\section{Tahap Perancangan: Peta Strategi dan Key Performance Indicator (KPI)}

Berdasarkan masukan dari tahapan strategi analisis, dirancang peta strategi perusahaan, yang kemudian diverifikasi melalui workshop, dan hasil verfifikasi diturunkan untuk merancang peta strategi teknologi informasi. Dilakukan workshop bersama Kepala Departemen dan Divisi TI untuk membangun Key Performance Indicator (KPI) yang terdiri dari definisi KPI, formula dan bobot.

\section{Tahap Evaluasi}

Pada tahap ini dibangun alat untuk evaluasi desain KPI yang telah dibangun dalam bentuk kuesioner, serta dilakukan kajian ulang dan rekomendasi penyempurnaan terhadap model rancangan yang dibangun.

\section{HASIL DAN PEMBAHASAN}

\section{Mengukur Kinerja TI (Measuring IT Performance)}

Semua pemimpin bisnis memiliki harapan yang kuat untuk dapat melihat peningkatan performa bisnis yang nyata sebagai hasil dari investasi suatu Teknologi Informasi (TI). Seiring dengan bahasa yang digunakan oleh bisnis, semua nilai harus dapat dikuantitatifkan atau diukur secara ekonomi (Ranti, 2006). Meningkatnya kebutuhan untuk mengukur nilai TI atau kinerja yang dihasilkan dalam berbagai bentuk manfaat dari penerapan TI, yang meliputi manfaat tangible dan intangible, and juga manfaat quasi intangible yang berdiri diantaranya, dinamakan IT Benefit Matrix (mengikuti terminologi Remenyi) yang diperkenalkan Remenyi (Remenyi et al, 1995) dan Parker ((Parker dan Benson, 1988, Parker, 1996) as follows: (1) easy-to-quantify tangible (EQT) atau hard benefit: Manfaat TI yang langsung mempengaruhi profitabilitas perusahaan dan dampaknya dapat secara langsung dilihat dan diukur secara objektif. Contoh: penurunan biaya dan peningkatan pendapatan; (2) hard-to-quantify tangible (HQT): Manfaat TI yang juga dapat dilihat secara langsung yang berdampak pada profit perusahaan, namun tidak dapat secara akurat diukur. Contoh: aliran informasi yang lebih baik dan meningkatkan keamanan perusahaan; (3) easy-to-quantify intangible (EQI): Manfaat TI yang dapat diukur, namun dampaknya tidak dapat secara langsung mempengaruhi profit perusahaan. Contohnya: peningkatan kepuasan pelanggan dan peningkatan kepuasan karyawan; (4) hard-to-quantify intangible (HQI) atau strategic/soft benefit: Manfaat TI yang tidak mudah untuk diukur dan dampaknya tidak secara langsung berpengaruh terhadap profit perusahaan. Contohnya: meningkatkan reaksi masyarakat dan meningkatkan image perusahaan. HQT dan EQI disebut sebagai penurunan dari manfaat quasi intangible dari TI. 


\section{Tahap Analisis}

\section{Analisis Permasalahan}

Untuk mengetahui kinerja Divisi IT berdasarkan penelitian sebelumnya berikut adalah hasil eksekutif interview bersama kepala Divisi TI tentang gambaran kinerja Divisi TI perusahaan PT XYZ (Tabel 1):

Tabel 1 Ringkasan Kinerja Divisi Teknologi Informasi( IT Division) yang Sedang Berjalan

\begin{tabular}{|c|c|}
\hline Area Manajemen & Kinerja Saat Ini \\
\hline - IT Work Force Management & $\begin{array}{l}\text { - Belum memiliki perencanaan karir dan renumerasi yang baik untuk } \\
\text { karyawanannya. Menghadapi masalah untk menemukan sistem } \\
\text { yang adil dalam sistem rewarding untuk karyawan berdasarkan } \\
\text { kinerja karena pengukuran yang ada saat ini dianggap tidak } \\
\text { memiliki pengukuran kinerja yang sesuai untuk menilai kinerja } \\
\text { sesungguhnya dari karyawan } \\
\text { Kurang tenaga kerja yang kompeten dan tingginya turn over di } \\
\text { Divisi TI yang hampir 16\%/tahun. }\end{array}$ \\
\hline - IT Risk Management & - $\quad$ Disaster Recovery Plan telah dibangun dengan baik \\
\hline $\begin{array}{l}\text { - IT Service Level } \\
\text { Management }\end{array}$ & $\begin{array}{l}\text { - Service Level Management untuk semua Departemen TI telah } \\
\text { dibentuk dan disetujui oleh user terkait sebelum diberlakukan }\end{array}$ \\
\hline $\begin{array}{l}\text { - IT Service, Asset and } \\
\text { Availability Management }\end{array}$ & $\begin{array}{l}\text { Butuh peningkatan dan ketepatan dalam pemberian servis terutama } \\
\text { - } \quad \text { Rengadaan barang sesuai dengan kebutuhan } \\
\text { rata } 80 \% \text { dari target } 85 \% \text {. } \\
\text { - } \quad \text { Penyelesaian proyek yang sering tidak tepat waktu }\end{array}$ \\
\hline $\begin{array}{l}\text { - IT Performance } \\
\text { Management }\end{array}$ & $\begin{array}{l}\text { - } \quad \text { Dibutuhkan pengukuran yang efektif untuk mengukur kinerja dan } \\
\text { kontribusi Divisi TI terhadap organisasi } \\
\text { - Kurangnya penilaian untuk mengukur kualitas dari sistem dan } \\
\text { dampak manfaat dari setiap proyek ITuntuk user. }\end{array}$ \\
\hline - IT Knowledge Management & $\begin{array}{l}\text { - Dokumentasi yang belum terintegrasi dengan sepenuhnya dan } \\
\text { menghadapi sedikit kesulitan dalam menelusuri urutan perubahan } \\
\text { terhadap modul dan aplikasi yang dibuat. } \\
\text { - Tidak adanya pedoman penggunaan aplikasi untuk user. }\end{array}$ \\
\hline $\begin{array}{l}\text { - IT Information Security and } \\
\text { Access Management }\end{array}$ & $\begin{array}{l}\text { - Temuan-temuan di mana user yang tidak berhak masih dapat aktif } \\
\text { sebagai pengguna sistem. }\end{array}$ \\
\hline - IT Compliance Management & $\begin{array}{l}\text { - Masih menghadapi kesulitan dalam pengaturan administrasi lisensi } \\
\text { yang digunakan dalam perusahaan dan cabang }\end{array}$ \\
\hline - IT Supplier Management & $\begin{array}{l}\text { - Tidak ada pengecekan yang dapat mengidentifikasi investasi yang } \\
\text { dilakukan secara efisien yang disertai manajemen negosiasi yang } \\
\text { baik atau tidak. }\end{array}$ \\
\hline $\begin{array}{l}\text { - IT Architecture } \\
\text { Management }\end{array}$ & $\begin{array}{l}\text { Dokumentasi arsitektur yang belum disempurnakan dengan } \\
\text { perubahan-perubahan yang sudah terjadi. Dibutuhkan waktu yang } \\
\text { cukup lama dalam analisis dampak ke sistem yang sedang berjalan } \\
\text { apabila ada sistem dan teknologi baru yang akan } \\
\text { diimplementasikan. }\end{array}$ \\
\hline
\end{tabular}

Departemen Pengembangan Sistem Informasi bertanggung jawab untuk pengembangan aplikasi dan pengembangan riset teknologi di semua bidang cabang di seluruh Indonesia. Departemen ini dibagi menjadi bagian fungsional beberapa yang setiap aplikasi menangani proyek permintaan dari satu daerah fungsi bisnis yang spesifik yang Loan Origination, Manajemen Kredit, Back Office dan Sistem Informasi Enterprise yang menangani proyek skala besar sedangkan Application Support 
(APS) mengembangkan skala kecil proyek (modul tambahan, kolom menambahkan, dll) dan juga mempertahankan aplikasi setelah empat departemen menerapkan sistem.

\section{Strategi Analisis}

Berdasarkan analisis lingkungan internal dan eksternal (melalui FGD dan EI), di bawah ini dikonfirmasi peta strategi untuk PT XYZ (Gambar 2). Peta strategi perusahaan dikembangkan hanya untuk menjadi dasar untuk mengembangkan TI peta strategi, maka, penanggung jawab, bobot, dan formula tidak dibahas dalam penelitian ini.

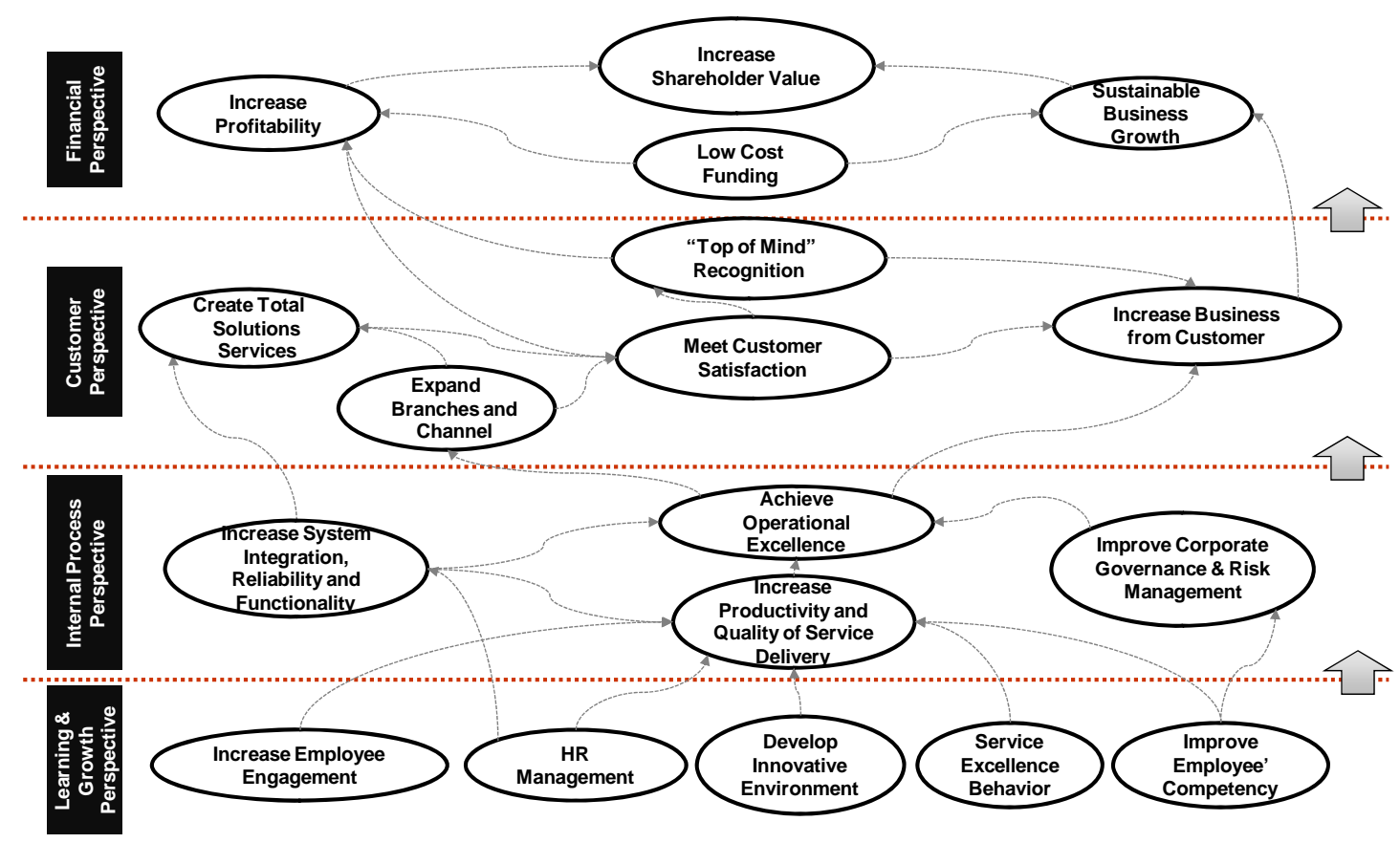

Gambar 2 Peta Strategi PT XYZ

Peta strategi perusahaan dikembangkan untuk diterjemahkan ke dalam peta strategi Organisasi TI, dan dapat menjadi arahan yang sangat baik kedepannya untuk mengembangkan KPI untuk semua posisi di Divisi IT. Peta strategi mengadopsi konsep Balanced Scorecard, yang terdiri dari empat perspektif yang digunakan dalam peta strategi.

Berdasarkan penelitian selanjutnya, berikut adalah peta strategi untuk organisasi TI berasal dari peta strategi perusahaan PT XYZ (Gambar 2). Strategi yang diadopsi dari peta strategi perusahaan adalah strategi yang terkait atau di bawah kendali organisasi TI. Strategi TI ditarik dalam peta strategi juga mempertimbangkan hasil analisis lingkungan internal dan eksternal (melalui FGD dan EI). Berikut ini adalah peta strategi organisasi TI dari PT .XYZ.

Disejajarkan dengan peta strategi perusahaan; strategi peta organisasi TI menggunakan empat perspektif. Namun, perspektif fokus TI mungkin berbeda dengan perspektif fokus perusahaan. Seperti gambar di atas menunjukkan bahwa perspektif proses internal memiliki strategi lebih dari perspektif lain. Strategi dalam peta strategi TI adalah keterkaitan dengan peta strategi perusahaan, seperti yang ditunjukkan pada Gambar 3. 


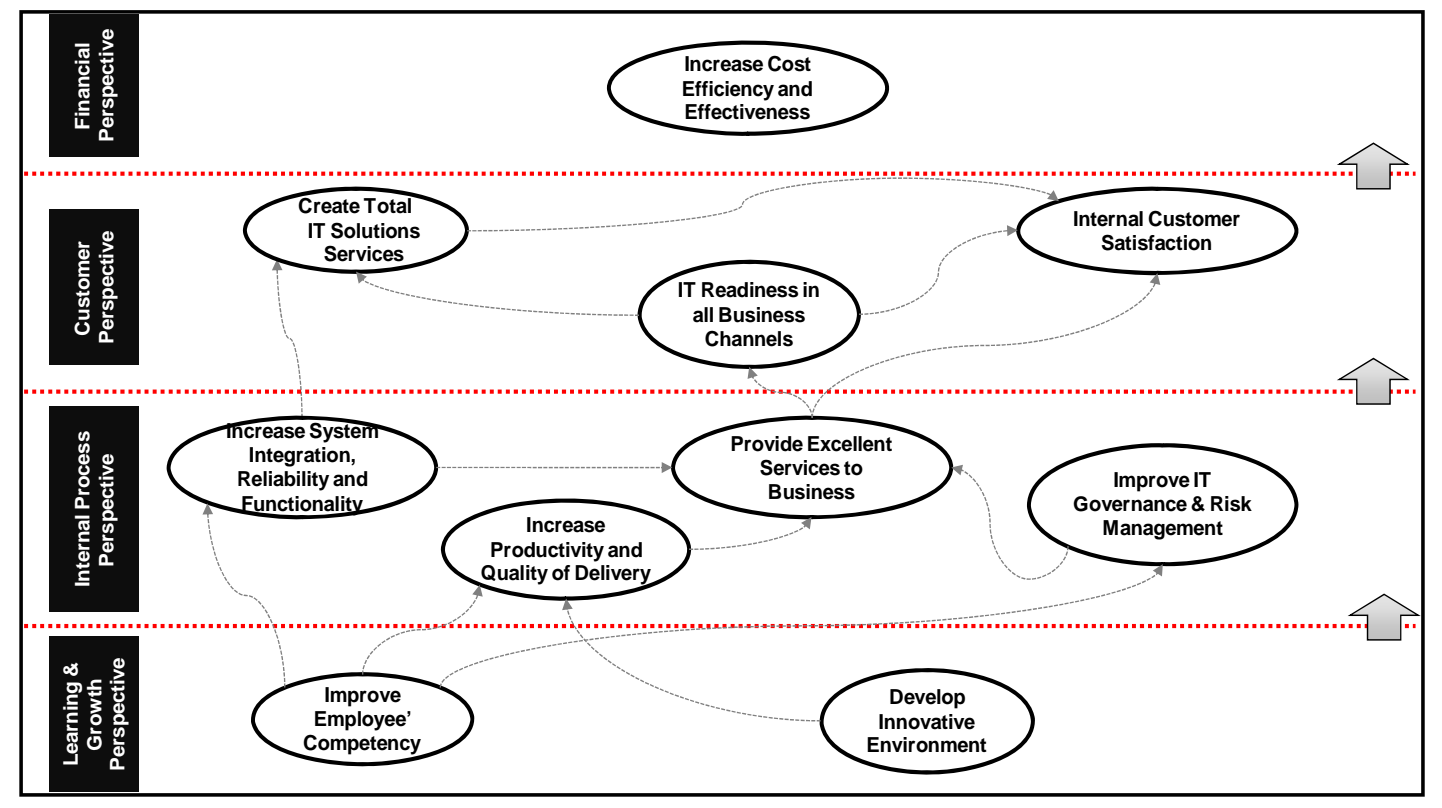

Gambar 2 Peta Strategi IT

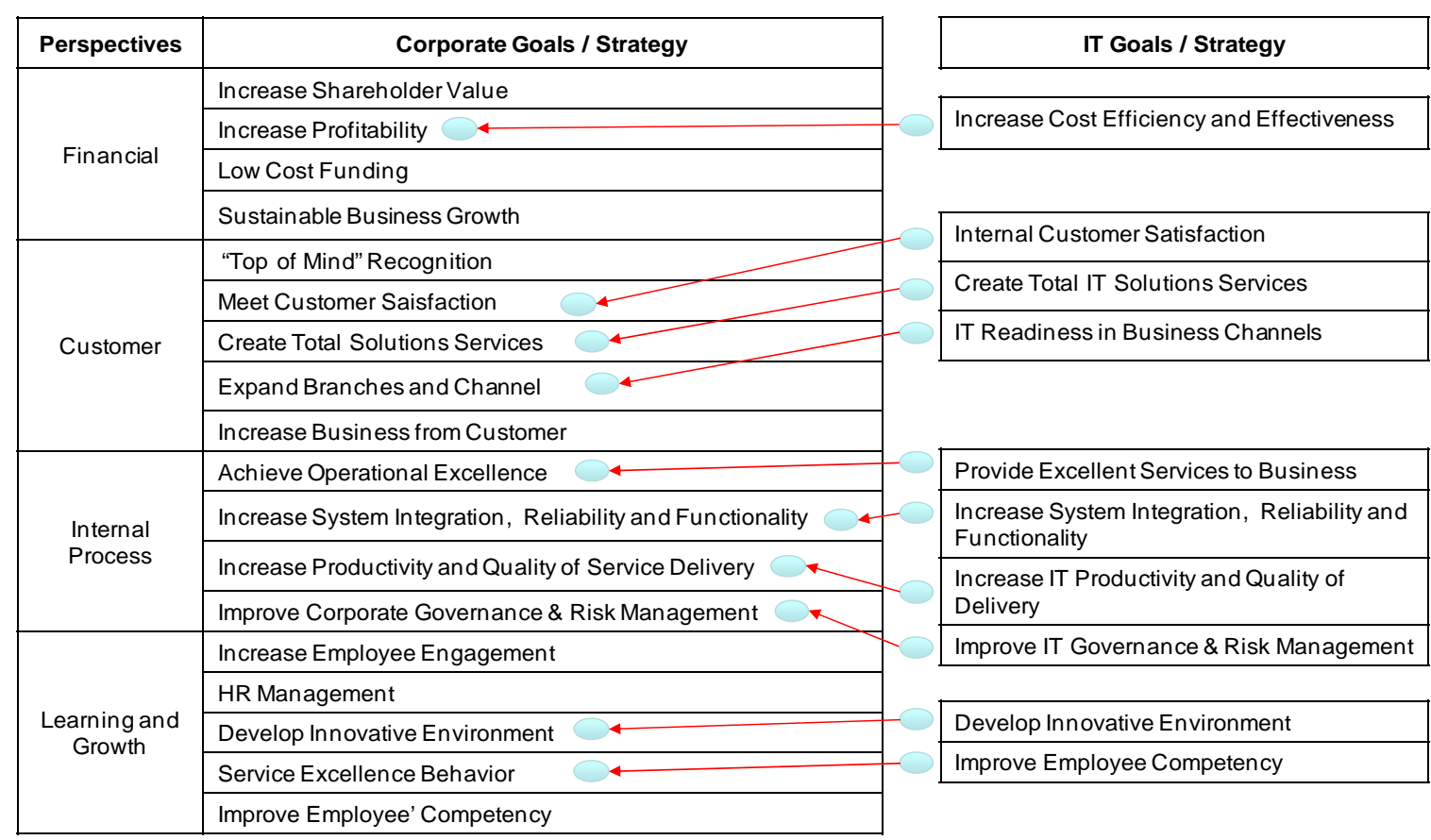

Gambar 3 Keterkaitan strategi perusahaan dan strategi TI

Meskipun fokus TI rentan terhadap proses internal, organisasi TI harus sangat berhati-hati dengan perspektif keuangan. Strategi TI dalam perspektif keuangan adalah untuk meningkatkan efisiensi dan efektivitas biaya. Investasi TI menghabiskan sejumlah besar biaya yang besar, maka kebutuhan TI untuk mengelola pengeluaran operasional dan modal perlu sejalan dengan pertumbuhan bisnis perusahaan. Manajemen PT XYZ mengharapkan TI untuk bertanggung jawab dalam penggunaan investasi. TI harus mampu menunjukkan bahwa investasi tidak sia-siadan mengembalikan 
proses bisnis yang lebih baik dalam organisasi sehingga akan ada penghematan biaya atau efisiensi karena TI.

Pada perspektif Customer, seperti halnya bagian penjualan, TI juga memiliki pelanggan yang menggunakan layanan mereka, pelanggan TI yang dikenal sebagai "pengguna" atau "pelanggan internal". Dalam perspektif pelanggan, strategi IT atau tujuan adalah untuk memenuhi kepuasan pelanggan internal. Di PT XYZ, pengguna memiliki daya tawar yang kuat untuk TI sehingga kinerja TI sangat tergantung pada kepuasan pengguna.

Pada perspektif internal process, strategi TI adalah untuk memberikan layanan terbaik untuk bisnis. Jika TI dapat memberikan layanan terbaik untuk bisnis, orang bisnis akan mampu memberikan nilai tambah bagi pelanggan. Tiga strategi untuk memberikan pelayanan yang sangat baik untuk bisnis dengan meningkatkan integrasi , kehandalan, dan fungsionalitas sistem, dengan meningkatkan produktivitas TI dan kualitas pengiriman; dengan meningkatkan tata kelola TI dan manajemen risiko. Integrasi sistem, kehandalan dan fungsionalitas mengarah ke proses bisnis yang efektif dan tidak "terganggu". Keamanan dan manajemen risiko yang penting untuk dikelola TI sejak dampak dari pelanggaran keamanan atau sistem bawah ini penting untuk bisnis perusahaan secara keseluruhan. Pengelolaan TI di PT XYZ juga perlu ditingkatkan, misalnya untuk dokumentasi belum selesai terintegrasi sehingga jika seseorang ingin melakukan peningkatan pada sistem yang mereka butuhkan perlu untuk mengulangi proses dari awal. Tenaga kerja yang berkompeten dan lingkungan yang inovatif adalah strategi bagaimana TI dapat mendukung tujuan bisnis. TI dapat membuat produk sesuai dengan permintaan pelanggan jika orang-orang IT memahami bisnis dan mendapatkan pengetahuan teknis terkait sistem. Permintaan dari pengguna dan teknologi berubah dengan cepat, maka IT butuh untuk lebih inovatif, menciptakan cara baru atau produk yang dapat mendukung bisnis.

Balanced scorecard untuk Divisi TI adalah berasal dari peta strategi TI (Tabel 2). Sebagian besar berada di bawah tanggung jawab CIO, beberapa KPI yang dianggap terlalu teknis akan mengalir untuk Kepala Divisi TI.

Tabel 2 Balanced Scorecard CIO dan Kepada Divisi TI

\begin{tabular}{|c|c|c|c|c|}
\hline Perspective & Goal & Measurement/ KPI & CIO & $\begin{array}{c}\text { Kepala } \\
\text { Divisi TI }\end{array}$ \\
\hline \multirow{2}{*}{ Financial } & \multirow{2}{*}{$\begin{array}{l}\text { Increase Cost Efficiency and } \\
\text { Effectiveness }\end{array}$} & TCO per Revenue or Profit & $\sqrt{ }$ & \\
\hline & & \% Actual Cost vs. Budget & & $\sqrt{ }$ \\
\hline \multirow{3}{*}{ Customer } & Create Total Solutions Services & Number of New Services & $\sqrt{ }$ & \\
\hline & $\begin{array}{l}\text { IT Readiness in all Business } \\
\text { Channels }\end{array}$ & $\begin{array}{l}\text { \% IT readiness in all business } \\
\text { channels }\end{array}$ & $\sqrt{ }$ & \\
\hline & Internal Customer Satisfaction & $\begin{array}{l}\begin{array}{l}\text { Internal } \\
\text { Index }\end{array} \\
\end{array}$ & & $\sqrt{ }$ \\
\hline \multirow{6}{*}{$\begin{array}{l}\text { Internal } \\
\text { Process }\end{array}$} & \multirow{2}{*}{$\begin{array}{l}\text { Increase System Integration, } \\
\text { Reliability and Functionality }\end{array}$} & $\%$ delivered project & & $\sqrt{ }$ \\
\hline & & \% System Running & & \multirow[t]{2}{*}{$\sqrt{ }$} \\
\hline & Increase Productivity and & Number of process improvement & $\sqrt{ }$ & \\
\hline & Quality of Delivery & through IT & & \\
\hline & $\begin{array}{l}\text { Improve IT Governance \& Risk } \\
\text { Management }\end{array}$ & Audit Rating & $\sqrt{ }$ & $\sqrt{ }$ \\
\hline & $\begin{array}{l}\text { Provide Excellent Services to } \\
\text { Business }\end{array}$ & SLA Rating & & $\sqrt{ }$ \\
\hline \multirow{2}{*}{$\begin{array}{l}\text { Learning } \\
\text { \& Growth }\end{array}$} & Improve Employee's Competency & Level of Innovation Index & $\sqrt{ }$ & \\
\hline & Develop Innovative Environment & \# of Innovation & & $\sqrt{ }$ \\
\hline
\end{tabular}




\section{Tahap Perancangan}

\section{Perancangan KPI Kepala Departemen Pengembangan Sistem Informasi}

Berdasarkan diskusi bersama Kepala Divisi TI dan Kepala Departmen Pengembangan Sistem Informasi PT XYZ, Tabel 3 berikut menunjukan KPI yang telah disepakati bersama Kepala Divisi dan kepala Departemen. Meskipun beberapa komponen KPI sama untuk posisi yang berbeda, namun objek pengukurannya masing-masing berbeda. Definisi key performance indicator dari perspektif financial dapat dilihat pada Tabel 4. Sedangkan definisi Key Performance Indicator dari perspektif Customer dapat dilihat pada Tabel 5. Selanjutnya Tabel 6 dan 7 secara berturut-turut adalah definisi key performance indicator dari perspektif internal process dan dari perspektif learning \& growth.

\section{Pembobotan Key Performance Indicator}

Berdasarkan hasil workshop bersama Kepala Divisi dan Kepada Departemen, berikut ini adalah hasil pembobotan KPI yang disepakati berdasarkan kepentingan dan prioritas KPI (Tabel 8).

Tabel 3 Balanced Scorecard Kepala Divisi TI dan Kepala Departemen Pengembangan Sistem Informasi

\begin{tabular}{|c|c|c|c|c|}
\hline Perspective & Strategy/ Goals & $\begin{array}{l}\text { Measurement/ } \\
\text { KPI }\end{array}$ & $\begin{array}{l}\text { Kepala } \\
\text { Divisi IT }\end{array}$ & $\begin{array}{c}\text { Kepala } \\
\text { Departemen } \\
\text { Pengembangan } \\
\text { SI } \\
\end{array}$ \\
\hline Financial & $\begin{array}{l}\text { Increase Cost } \\
\text { Efficiency and } \\
\text { Effectiveness }\end{array}$ & $\begin{array}{l}\text { \% Actual Cost vs. } \\
\text { Budget }\end{array}$ & $\sqrt{ }$ & $\sqrt{ }$ \\
\hline Customer & $\begin{array}{l}\text { Internal Customer } \\
\text { Satisfaction }\end{array}$ & $\begin{array}{l}\text { Internal Customer } \\
\text { Satisfaction Index }\end{array}$ & $\sqrt{ }$ & $\sqrt{ }$ \\
\hline \multirow{4}{*}{$\begin{array}{l}\text { Internal } \\
\text { Process }\end{array}$} & \multirow{2}{*}{$\begin{array}{l}\text { Increase System } \\
\text { Integration, } \\
\text { Reliability and } \\
\text { Functionality }\end{array}$} & $\begin{array}{l}\text { \% Delivered } \\
\text { project }\end{array}$ & $\sqrt{ }$ & $\sqrt{ }$ \\
\hline & & \% System Running & $\sqrt{ }$ & $\sqrt{ }$ \\
\hline & $\begin{array}{l}\text { Improve IT } \\
\text { Governance \& Risk } \\
\text { Management }\end{array}$ & Audit Rating & $\sqrt{ }$ & $\sqrt{ }$ \\
\hline & $\begin{array}{l}\text { Provide Excellent } \\
\text { Services to Business }\end{array}$ & SLA Rating & $\sqrt{ }$ & \\
\hline \multirow{2}{*}{$\begin{array}{l}\text { Learning } \\
\text { and } \\
\text { Growth }\end{array}$} & \multirow{2}{*}{$\begin{array}{l}\text { Improve Employee's } \\
\text { Competency }\end{array}$} & Competency set & & $\sqrt{ }$ \\
\hline & & \# of Innovation & $\sqrt{ }$ & $\sqrt{ }$ \\
\hline
\end{tabular}

Tabel 4 Definisi KPI dari Perspektif Financial

\begin{tabular}{|c|c|c|c|c|}
\hline KPI & Definisi & Formula & Metriks & Keterangan \\
\hline $\begin{array}{l}\% \quad \text { Actual } \\
\text { Cost/ } \\
\text { Budget }\end{array}$ & $\begin{array}{l}\text { Perbedaan realisasi } \quad \text { dana } \\
\text { dengan anggaran organisasi TI }\end{array}$ & $\begin{array}{l}\text { Actual Cost/ Budget } \\
\text { (OPEX, CAPEX) }\end{array}$ & $\%$ & $\begin{array}{l}\text { +/- dari standar yang } \\
\text { ditentukan }\end{array}$ \\
\hline
\end{tabular}

Tabel 5 Definisi KPI dari Perspektif Customer

\begin{tabular}{|c|c|c|c|c|c|c|}
\hline KPI & & Definisi & & Formula & Metriks & Keterangan \\
\hline $\begin{array}{l}\text { Customer } \\
\text { Satisfaction }\end{array}$ & $\begin{array}{l}\text { Indeks } \\
\text { Customer }\end{array}$ & $\begin{array}{c}\text { dihasilkan } \\
\text { Satisfaction }\end{array}$ & $\begin{array}{r}\text { dari } \\
\text { Survey }\end{array}$ & $\begin{array}{l}\text { Hasil } \\
\text { Customer }\end{array}$ & Indeks & $\begin{array}{l}\text { Indeks lebih besar, } \\
\text { performa lebih baik }\end{array}$ \\
\hline
\end{tabular}




\begin{tabular}{|c|c|c|c|c|}
\hline KPI & Definisi & Formula & Metriks & Keterangan \\
\hline Index & $\begin{array}{lll}\text { yang diisi } & \text { pengguna TI dari } \\
\text { internal } & \text { perusahaan } & \text { dua } \\
\text { kali/tahun. } & & \\
\end{array}$ & Satisfaction Survey & & \\
\hline $\begin{array}{l}\text { SLA (Service } \\
\text { Level } \\
\text { Agreement) } \\
\text { Rating }\end{array}$ & 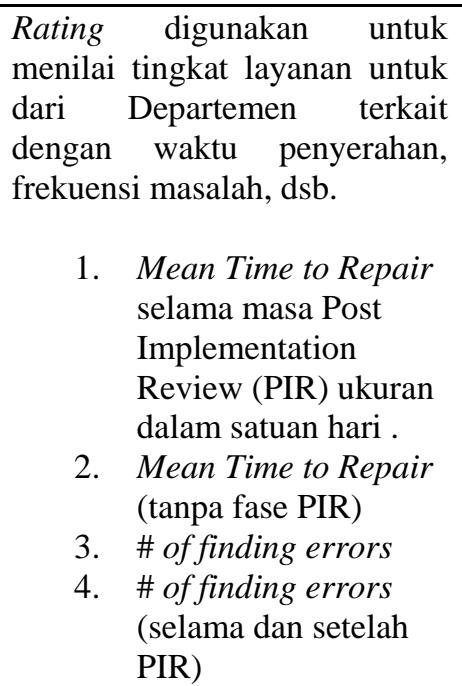 & $\begin{array}{l}\text { Formula dalam } \\
\text { satuan waktu: } \\
\text { \% tepat sesuai SLA: } \\
\text { (Committed time - } \\
\text { Gap Time )/ } \\
\text { Committed time } \\
\text { Atau } \\
\text { Jika formula dengan } \\
\text { angka: } \\
\text { (target frekuensi - } \\
\text { frekuensi realisasi)/ } \\
\text { target frekuensi }\end{array}$ & $\%$ & $\begin{array}{c}\text { \% lebih besar, } \\
\text { performa lebih baik }\end{array}$ \\
\hline
\end{tabular}

Tabel 6 Definisi KPI dari Perspektif Internal Process

\begin{tabular}{|c|c|c|c|c|}
\hline KPI & Definisi & Formula & Metriks & Keterangan \\
\hline $\begin{array}{l}\text { \% Delivered } \\
\text { Project }\end{array}$ & $\begin{array}{l}\text { Jumlah proyek yang } \\
\text { diimplementasikan pada fase } \\
\text { produksi (production phase) } \\
\text { Dibagi dengan total proyek } \\
\text { yang diminta pada waktu } \\
\text { tersebut }\end{array}$ & $\begin{array}{l}\text { Kepala } \\
\text { Departemen: } \\
\text { \# Implementasi } \\
\text { Proyek } \\
\text { / } \\
\text { \# Total Permintaan } \\
\text { Proyek selama } \\
\text { Periode } \\
\text { Section Head: } \\
\text { (\#Project fase } \\
\text { "Closed “- } \\
\text { \#Project pada fase } \\
\text { PIR } \\
\text { / } \\
\text { \# Total Permintaan } \\
\text { Proyek) * 100\% }\end{array}$ & $\%$ & $\begin{array}{l}\text { \% lebih besar, } \\
\text { performa lebih baik }\end{array}$ \\
\hline $\begin{array}{l}\text { \% System } \\
\text { Running }\end{array}$ & $\begin{array}{l}\text { Untuk mengukur } \\
\text { ketersediaan sistem dalam } \\
\text { perusahaan. } \\
\text { Committed Time = Jumlah } \\
\text { jam yang ditargetkan sistem } \\
\text { dalam kondisi tersedia } \\
\text { GAP Time = Jumlah jam } \\
\text { sebenarnya - Committed } \\
\text { Time } \\
\text { DAN }\end{array}$ & $\begin{array}{l}\text { Kombinasi } \\
\text { perhitungan dari: } \\
\text { (Committed time - } \\
\text { Gap Time)/ } \\
\text { Committed time } \\
\text { DAN } \\
\text { (Frekuensi masalah } \\
\text { yang ditolerir- } \\
\text { Frekuensi yang }\end{array}$ & $\%$ & $\begin{array}{l}\text { \% lebih besar, } \\
\text { performa lebih baik } \\
\text { Angka insiden yang } \\
\text { kecil } \\
\text { mengindikasikan } \\
\text { performa yang lebih } \\
\text { baik } \\
\text { Komponen ini dapat } \\
\text { menggambarkan } \\
\text { kualitas dari }\end{array}$ \\
\hline
\end{tabular}




\begin{tabular}{|c|c|c|c|c|}
\hline KPI & Definisi & Formula & Metriks & Keterangan \\
\hline & $\begin{array}{l}\text { Jumlah masalah/insiden } \\
\text { yang membuat sistem tidak } \\
\text { tersedia dalam periode } \\
\text { tertentu dibagi dengan } \\
\text { jumlah masalah/insiden yang } \\
\text { ditoleransi }\end{array}$ & $\begin{array}{l}\text { terjadi)/ Frekuensi } \\
\text { masalah yang } \\
\text { ditolerir }\end{array}$ & & $\begin{array}{l}\text { manajemen insiden } \\
\text { dalam organisasi TI } \\
\text { dalam } \\
\text { mempertahankan } \\
\text { kelangsungan bisnis } \\
\text { perusahaan. }\end{array}$ \\
\hline $\begin{array}{l}\text { \% of Project } \\
\text { in Time } \\
\text { Delivery }\end{array}$ & $\begin{array}{l}\text { Untuk mengukur ketepatan } \\
\text { dalam penyelesaian proyek } \\
\text { di dalam periode waktu yang } \\
\text { telah disepakati. } \\
\text { Rata-rata katerlambatan } \\
\text { (hari) untuk penutupan } \\
\text { proyek (setelah masa PIR) } \\
\text { selama periode tertentu } \\
\text { dibagi lama waktu (hari) } \\
\text { yang diberikan untuk } \\
\text { penyelesaian proyek }\end{array}$ & $\begin{array}{l}\text { Project Time Spend } \\
= \\
1 \text { - (Average of } \\
\text { overdue time (day) } \\
\text { in Closing Project } \\
\text { / } \\
\text { project time plan } \\
(\text { day) })^{*} 100 \%\end{array}$ & $\%$ & $\begin{array}{l}\text { \% lebih besar, } \\
\text { performa lebih baik } \\
\text { Angka dapat >100\% } \\
\text { jika proyek selesai } \\
\text { kurang dari waktu } \\
\text { yang ditentukan (hari) }\end{array}$ \\
\hline Audit Rating & $\begin{array}{l}\text { Rating yang diberikan dari } \\
\text { proses audit dari eksternal } \\
\text { auditor selama periode } \\
\text { waktu tertentu }\end{array}$ & $\begin{array}{l}\text { Berdasarkan Audit } \\
\text { Findings }\end{array}$ & Rating & $\begin{array}{l}\text { Rating lebih besar, } \\
\text { performa lebih baik }\end{array}$ \\
\hline
\end{tabular}

Tabel 7 Definisi KPI dari Perspektif Learning \& Growth

\begin{tabular}{|c|c|c|c|c|}
\hline KPI & Definisi & Formula & Metriks & Keterangan \\
\hline $\begin{array}{l}\text { \# of } \\
\text { Innovation }\end{array}$ & $\begin{array}{l}\text { Jumlah Inovasi yang } \\
\text { diajukan dan atau } \\
\text { diimplementasikan selama } \\
\text { periode waktu tertentu }\end{array}$ & $\begin{array}{l}\text { \# of proposed or } \\
\text { implemented } \\
\text { innovation } \\
\text { / targeted number }\end{array}$ & $\%$ & $\begin{array}{l}\text { \% lebih besar, performa } \\
\text { lebih baik }\end{array}$ \\
\hline $\begin{array}{l}\text { Competency } \\
\text { set }\end{array}$ & $\begin{array}{l}\text { Jumlah posisi yang set } \\
\text { kompetensinya telah } \\
\text { disetujui dibagi dengan } \\
\text { target yang ditentukan } \\
\text { selama periode waktu } \\
\text { tertentu }\end{array}$ & $\begin{array}{l}\text { \# approved } \\
\text { competency set } \\
\text { (position } \\
/ \\
\text { targeted number of } \\
\text { competency set (all } \\
\text { positions) }\end{array}$ & $\%$ & $\begin{array}{l}\text { \% lebih besar, performa } \\
\text { lebih baik }\end{array}$ \\
\hline
\end{tabular}

Tabel 8 Pembobotan KPI untuk Departemen Pengembangan Sistem Informasi

\begin{tabular}{llll}
\hline Perspective & \multicolumn{1}{c}{ Strategy/ Goals } & Measurement/ KPI & $\begin{array}{c}\text { Kepala } \\
\text { Departemen } \\
\text { Pengembangan } \\
\text { SI }\end{array}$ \\
\hline Financial & $\begin{array}{l}\text { Increase Cost Efficiency and } \\
\text { Effectiveness }\end{array}$ & \% Actual Cost vs. Budget & $15 \%$ \\
\hline Customer & Internal Customer Satisfaction & $\begin{array}{l}\text { Internal Customer } \\
\text { Satisfaction Index }\end{array}$ & $15 \%$ \\
\hline $\begin{array}{l}\text { Internal } \\
\text { Process }\end{array}$ & $\begin{array}{l}\text { Increase System Integration, } \\
\text { Reliability and Functionality }\end{array}$ & \% Delivered project & $12 \%$ \\
\hline
\end{tabular}




\begin{tabular}{lllr}
\hline \multirow{2}{*}{$\begin{array}{c}\text { Perspective } \\
\end{array}$} & \multicolumn{1}{c}{ Strategy/ Goals } & Measurement/ KPI & \multicolumn{2}{c}{$\begin{array}{c}\text { Kepala } \\
\text { Departemen } \\
\text { Pengembangan } \\
\text { SI }\end{array}$} \\
\cline { 2 - 4 } & $\begin{array}{l}\text { Improve IT Governance \& Risk } \\
\text { Management }\end{array}$ & Audit Rating & $20 \%$ \\
\cline { 2 - 4 } & Provide Excellent Services to Business & SLA Rating & $9 \%$ \\
\hline $\begin{array}{l}\text { Learning } \\
\text { and } \\
\text { Growth }\end{array}$ & Improve Employee's Competency & Competency set & $10 \%$ \\
\cline { 3 - 4 } & & \# of Innovation & $8 \%$ \\
\hline
\end{tabular}

\section{Tahap Evaluasi}

Setelah dilakukan pembobotan KPI, dilakukan workshop bersama Kepala Divisi dan Kepala Departemen untuk melakukan evaluasi efektifitas pengukuran/KPI yang telah dirancang melalui beberapa faktor: (1) alignment with business strategy; (2) quantifiable; (3) accessibility of supporting data; (4) understandable and actionable; (5) no conflict with other performance measurement; (6) relevance with the job roles and responsibility; (7) clear definition; (8) controllable; (9) credible, not easy to be manipulated; (10) efficient, effort and cost to measure performance is lower than the benefit.

Hasil evaluasi (Tabel 9) menyatakan bahwa KPI yang telah dirancang sesuai dengan harapan mereka dalam mengidentifikasi pengukuran kinerja Kepala Departemen dalam menyelaraskan target kinerjanya untuk mendukung pencapaian strategi perusahaan.

Tabel 9 Hasil Evaluasi Key Performance Indikator

\begin{tabular}{lc}
\hline \multicolumn{1}{c}{ Kategori } & Rata-rata \\
\hline Alignment & 5 \\
\hline Quantifiable & 5 \\
\hline Accessibility & 3 \\
\hline Understandable \& Actionable & 4 \\
\hline Counter-balanced & 4 \\
\hline Relevance & 5 \\
\hline Common definition & 4 \\
\hline Controllable & 4 \\
\hline Credible & 3 \\
\hline Efficient & 5 \\
\hline Rata-rata & $\mathbf{4 . 2}$ \\
\hline
\end{tabular}

Keterangan: 1 - Sangat tidak sesuai 2 - Tidak Sesuai 3 -Cukup $\quad 4$-Sesuai 5 - Sangat Sesuai

\section{PENUTUP}

Kerberhasilan Departemen Pengembangan Sistem Informasi bukanlah sebuah keberhasilan yang terpisah, melainkan perlu sejalan dengan target keberhasilan organisasi TI secara umum dan target perusahaan secara menyeluruh. Teknik Balanced Scorecard membantu mengintegrasikan pengukuran yang seimbang antara indikator finansial maupun non-finansial. Fleksibilitas yang tinggi yang ditawarkan dengan metode ini memungkinkan pengukuran dengan perbedaan level formula pada komponen pengukuran yang sama, yang ditujukan untuk posisi yang berbeda yang memiliki tanggung 
jawab yang berbeda. Pengkajian ulang sistem pengukuran seiring dengan pembaruan strategi dan tujuan Departemen tetap perlu dilakukan secara berkesinambungan dalam menyelaraskan pengukuran yang ada dengan pengukuran baru yang memiliki keterkaitan dengan strategi bisnis. Sehingga diharapkan Departemen dapat melaju di dalam strategi yang sama dengan perusahaan, dan dapat berkontribusi secara maksimal dengan peningkatan kinerja yang berkesinambungan.

\section{DAFTAR PUSTAKA}

Kaplan, Robert S. \& Northon, David P. (2004). Strategy Maps Converting Intangible Assets to Tangible Outcomes. Boston: Harvard Business School Press.

Kaplan, Robert S. and Norton, David P. (2001). The Strategy Focused Organization: How Balanced Scorecard Companies Thrive in the New Business Environment. Boston: Harvard Business School Press.

Mulyadi. (2001). Balanced Scorecard: Alat Manajemen Kontemporer untuk Pelipatganda Kinerja Keuangan Perusahaan (edisi ke-2). Jakarta: Salemba Empat.

Parker, Marilyn M. (1996). Strategic Transformation and Information Technology: Paradigms for Performing While Transforming. New Jersey: Prentice-Hall.

Parker, Marilyn M., Benson, Robert. (1988). Information Economics: Linking BusinessPerformance to Information Technology. New Jersey: Prentice-Hall.

Ranti, Benny. (2006). A review of information technology investment evaluation methodologies: the need for appropriate evaluation methods. Prosiding Konferensi Nasional Teknologi Informasi \& Komunikasi untuk Indonesia 3-4 Mei 2006, Aula Barat \& Timur Institut Teknologi Bandung.

Remenyi, Dan et al. (1995). Effective Measurement and Management of IT Costs and Benefits, Oxford: Butterworth-Heinemann. 